\section{RAT-BITE FEVER.}

To the Editor of THE LANCET.

SIR. - I am very interested in the account of " A Case of Rat-bite Fever," by Captain S. R Douglas, I.M.S., Captain I. Colebrook, R.A.M.C., and Lieutenant A. Fleming, R.A.M.C., in your issue of $\mathrm{Feb}$. 16th. The case seems to have very closely resembled a typical one of this disease, and yet the observers found no spirochæetes but a streptococcus, which they proved conclusively was the cause of the illness, and the administration of a vaccine made from this streptococcus cured the patient. It is conceivable and highly probable that a fever clinically resembling rat-bite fever might be caused by numerous different organisms; in one case a spirochæte, in another a streptothrix, and in a third a streptococcus.

Those who have followed the account of the work of the several Japanese observers in the recent numbers of the Journal of Experimental Medicine can have no doubt that typical rat-bite fever, as met with in Japan, has been conclusively proved to be due to a spirochæte-the Spirochata morsus muris (Futaki), but its detection in the glands, excised skin of the affected part, and particularly in the peripheral blood of a patient is a matter of great difficulty.

My reason for writing is not a controversial one. I know very little about the subject from a clinical standpoint, and have only seen one definitive case, that of a lady bitten in the finger by a ferret. This was before the discovery of the Japanese had appeared. I examined in the afebrile period the blood and exudation from the wound, but with negative results. I have, however, just finished a long and very laborious work which has taken much of my time for a year. In February of last year I started to see if I could detect in the kidney of the common rat either primarily the $S p$. isterohemorrhagice of infective jaundice, or secondarily the $s p$. morsus muris of rat-bite fever. I have completed the examination of 100 rats (Mus decumanus) caught in the town and country around, and $I$ have found that 9 per cent. carry definite $S p$. icterohamorrhagie.

[Details of the methods, description of the spirochates, with photo-micrographs at a magnification of from 2000 to 4000 diameters, showing the minute curls of the spirochæte which Noguchi was the first, and only one, to point out, and of which he says, "So far no satisfactory micro-photograph has been reproduced," are in the press and will appear shortly.] During the whole of that examination I only once met with any other spirochæte, and that was in the eightyfourth rat, one about half-grown from the country. These resembled very closely the $S p$. morsus muris of rat-bite fever in size, shape. and staining reaction; they were short, thick, and rigid. The average measurement of 65 examples was $5.45 \mu$ long, with 2.2 turns or waves. These, I have little doubt, are the spirochætes of rat-bite fever described and figured by the Japanese workers, but until I have either seen their preparations or have found similar spirochætes in cases of rat-bite fever in England the question must remain sub judice.

This brings me to the reason of my writing.

1. Can any of your readers lend me a slide showing the Japanese spirochæte in order that I may examine and take photo-micrographs?

2. Will those who meet another case of rat-bite fever kindly send me an excised gland or smears from an excised or punctured gland and blood-films taken from the skin at the seat of the rash or wound, both only during a febrile attack? I am, Sir, yours faithfully,

York House, Poole-road, Bournemouth, Feb. 19th, 1918. Alfred C. Coles.

\section{THE CHOICE OF AN ASSTHETIC IN SEVERE INJURIES.}

To the Editor of THE LANCET.

SIR,-It would be interesting to know whether surgeons and anæsthetists who are called upon to treat civilians' wounds during air raids have profited by the experience of the men at the front and insist on administering nitrous oxide and oxygen as the anæsthetic for the severely wounded. People wounded during a raid are in much the same condition as soldiers wounded at the front, and one knows that whenever it is possible gas and oxygen is selected as the anæsthetic of choice.

The reasons for this choice need not be entered into here; but it seems a pity that our civilian wounded should not be given just as good a chance of recovery as our soldiers.

I am, Sir, yours faithfully,

H. FDMUND G. BOYie.

Upper Wimpole-street, W., Feb. 23rd, 1918.

\section{A COMMON ORIGIN FOR SHINGLES AND CHICKEN-POX.}

To the Editor of THE LANCET.

SIR,-An outbreak of chicken-pox among my own children seems to afford further support of Dr. W. $P$. Le Feuvre's theory, as discussed in an annotation in THE LANCET of Feb. 16th. On Oct. 8th, 1917, I went to stay with the three children in a house where the maid, with whom they spent much of their time, was suffering from an attack of herpes zoster. As far as I can remember, the distribution of the rash was that of the fourth cervical and third dorsal segments on the right side. We returned home by train on Oct. 15th; on Oct. 27th my elder boy, aged 5 showed a scanty generalised chicken-pox rash, but possibly the disease started on the $24 \mathrm{th}$, as on that day he vomited several times, and on the next or following day had a raw spot on the neck which may have been a vesicle ruptured by scratching or rubbing. I know of no source of infec. tion. The two younger children developed chicken-pox on Nov. 8th. Feb. 19th, 1918. I am, Sir, yours faithfully, IVY E. HASLAM

\section{ACRIFLAVINE AND PROFLAVINE. To the Editor of THE LANCET.}

SIR,-I wish to correct an error and to make good an omission occurring in my paper in your issue of Feb. 16th dealing with the action of these substances.

In the first series of experiments I found that staphylococci grew in defibrinated blood in the presence of $1 / 60,000$ acriflavine. The text, as I wrote it, gave 1/160,000.

Again, in comparing the effect of the antiseptics on the growth of staphylococci in serum and broth respectively omitted to state that the organisms grew freely in broth in the presence of (1) $1 / 30,000$ acriflavine, (2) $1 / 10,000$ pro flavine. This was in contrast with the case of serum, where there was no obvious growth in the same concentrations. I am, Sir, yours faithfully,
anth in the same conce

France. WM. PARRY MORgaN.

\section{THE OLD FPSOMIAN CLUB.}

To the Editor of THE LANCET.

SIR, - A meeting of the members of the old Epsomian Club will be held at the office of Epsom College, 37, Soho. square, on Tuesday, March 5th, at 4.30 P.M. As the list of addresses is so full of errors notice of the meeting will only be given in this form. In addition to the ordinary business the meeting must decide what sum is to be given by the club to the Epsom College War Memorial Fund.

I am, Sir, yours faithfully,

37, Harley street, W., Feb. 22nd, 1918. EDREN M. CORner.

Miss E. E. Violet Glover has been admitted to the degree of Doctor of Medicine in the University of Leeds. She is the first woman who has taken this degree in the University.

The Late Dr. J. BarroN.-John Barron, who died on Feb. 10th, at Belfast, at the age of 57 , had been in failing health for some years. He was born in County Antrim and was educated at the Royal Academical Insti. tution, and at Queen's College, Belfast, and graduated M.D. of the Royal University of Ireland in 1885. Starting practice in Belfast, he succeeded his brother, Dr. James Barron, as dispensary doctor of No. 2 Belfast Poor-law district. Up to about four years ago he had a large practice, especially among the poor, by whom he was greatly liked, but at that time impaired bealth obliged him to givo up his dispensary work and he has since gradually relinquished practice. He was at various times a member of the city council and of the Belfast Water Board. His wife predecensed him, and he leaves a daughter. 